\title{
Effect of Planting Methods and Seeding Rates on Rice Yields ${ }^{1,2}$
}

\author{
José M. Lozano and Fernando Abruña ${ }^{3}$ \\ ABSTRACT
}

\begin{abstract}
Seeding rates of rice varying from 70 to $135 \mathrm{~kg} /$ ha did not affect grain yields produced by the Caloro variety drilled at 20 and $30 \mathrm{~cm}$ between rows but yields were higher with the closer row spacings. When broadcast, the Girona variety produced higher yields when seeding rates were increased from 70 to $115 \mathrm{~kg} / \mathrm{ha}$, but no further increases occurred with seeding rates up to $155 \mathrm{~kg} / \mathrm{ha}$. Seeding rates varying from 70 to $155 \mathrm{~kg} / \mathrm{ha}$ had no effect on yields of the Bahía variety. Increasing seeding rates with the Brazos variety from 110 to $450 \mathrm{~kg} / \mathrm{ha}$ did not affect yields, but yields were reduced with a seeding rate of $560 \mathrm{~kg} / \mathrm{ha}$. Girona seedlings transplanted 40 days after seeding yielded less than when transplanted at 20 or 30 days. Direct seeding of Girona resulted in yields similar to those obtained with seedlings transplanted 21 days after seeding.
\end{abstract}

\section{INTRODUCTION}

Rice is the major food crop of the tropics. Over 170 million tons are produced annually on about 95 million ha (13). Most of the rice is transplanted, but direct seeding either in dry or flooded soils is used in mechanized operations in the USA, Australia, and other countries.

In California, where most of the rice is seeded by air in flooded fields, about $170 \mathrm{~kg} / \mathrm{h}$ a of pregerminated seed is sown (3). Nelson (10) reported fewer weeds with high seeding rates, but yields were highest with the lowest rate (80 kg of seed/ha). Later, Simmons (14) reported that the best rate was from 100 to $125 \mathrm{~kg} /$ ha for drill seeding, and from 125 to 150 $\mathrm{kg} / \mathrm{ha}$ for broadcasting. Reynolds (11) found that seeding rates in Texas ranged from 70 to $140 \mathrm{~kg} / \mathrm{ha}$ and averaged $100 \mathrm{~kg} / \mathrm{ha}$. In an experiment with Bluebonnet 50, similar yields were produced by broadcasting 100 , 150 and $200 \mathrm{~kg}$ of seed/ha, but lowest yields were produced with $50 \mathrm{~kg}$ / ha. Jones et al. (4), summarizing the rate of seeding experiments with drilled rice, found that under favorable conditions $90 \mathrm{~kg} / \mathrm{ha}$ was usually sufficient to get a good stand. Yields were seldom increased and were sometimes reduced by higher seeding rates. They point out that under normal weather conditions in the southern states, 100 to $110 \mathrm{~kg}$ of seed/ ha drilled and $170 \mathrm{~kg} / \mathrm{ha}$ broadcast usually provide a good stand.

Rice is usually transplanted throughout the tropics. Optimum age for

${ }^{1}$ Manuscript submitted to Editorial Board January 26, 1981.

${ }^{2}$ This paper covers work carried out cooperatively between the Agricultural Research, Science, and Education Administration, USDA, and the Agricultural Experiment Station, College of Agricultural Sciences, Mayagüez Campus, University of Puerto Rico, Rio Piedras, P.R.

${ }^{3}$ Research Assistant, Agricultural Experiment Station, College of Agricultural Sciences, Mayagüez Campus, University of Puerto Rico, Rio Piedras, P.R., and Soil Scientist, Agricultural Research, Science and Education Administration, USDA. 
transplanting varies with variety and weather. Leonard (5) found that the best age for transplanting rice in Japan is 40 to 60 days after seeding, and Brown (1) reported that in Malaysia 45 to 65 days seems best. Sánchez and Larrea (12) in Peru found that age at transplanting significantly affected yields. The IR 8 variety produced highest yields ( $12 \mathrm{t} / \mathrm{ha}$ ) when transplanted at 30 days. Delayed transplanting reduced plant height, dry matter production and fertile grains per panicle. Cada and Taleon (2) found that early maturing varieties were severely affected by delays in transplanting.

The present study determined the effect of seeding rates, planting distances and age at transplanting on yields of four rice varieties.

\section{MATERIALS AND METHODS}

Experiments were carried out at the Gurabo Substation on Coloso clay, a fine, mixed, nonacid, isohyperthermic Aeric Tropic Fluvaquents (9). The chemical properties of this soil have been described by Lozano and Abruño (6).

In the first experiment, yields of two short grain, early maturing Spanish varieties (Girona and Bahía) were compared at seeding rates of $70,90,115,135$ and $155 \mathrm{~kg} /$ ha broadcast, and yields of the short grain Caloro variety were determined at two row spacings $(20$ and $30 \mathrm{~cm}$ ) and 4 seeding rates $(70,90,115$ and $135 \mathrm{~kg} / \mathrm{ha})$.

A second experiment compared yields of Brazos, a medium grain variety, at seeding rates of $112,225,335,450$ and $560 \mathrm{~kg} /$ ha broadcast.

The third experiment determined the effect of age of Girona seedlings at transplanting on yields. Seedlings were grown in a seedbed planted by broadcasting $400 \mathrm{~kg}$ of seed/ha and fertilized 2 weeks later with $110 \mathrm{~kg} /$ ha of $\mathrm{N}, \mathrm{P}_{2} \mathrm{O}_{5}$ and $\mathrm{K}_{2} \mathrm{O}$. No herbicide was applied since the dense stand of rice prevented weed growth. Seedlings were transplanted 20, 30 and 40 days after seeding in $20-\mathrm{cm}$ rows with $5 \mathrm{~cm}$ between plants. All plots received $110 \mathrm{~kg}$ of $\mathrm{N}, \mathrm{P}_{2} \mathrm{O}_{5}$ and $\mathrm{K}_{2} \mathrm{O} /$ ha two days after transplanting.

In the fourth experiment, with the Girona variety, direct seeding was compared to transplanting with 30 -day-old seedlings. Direct seeding was at the rate of $140 \mathrm{~kg} / \mathrm{ha}$. Seedlings were planted $5 \mathrm{~cm}$ apart in $20-\mathrm{cm}$ rows.

In all experiments, plots were $3.1 \times 3.1 \mathrm{~m}$ arranged in a randomized block design with treatments replicated four times. The experimental area was surrounded by levees in order to maintain a permanent flood. Weeds were controlled with propanil applied at the rate of $15 \mathrm{~L} / \mathrm{ha}$ when weeds were in the $2-4$ leaf stage. All plots received $110 \mathrm{~kg} / \mathrm{ha}$ each of $\mathrm{N}, \mathrm{P}_{2} \mathrm{O}_{5}$ and $\mathrm{K}_{2} \mathrm{O}$, one-half applied at planting and the remainder at panicle initiation. Insects and diseases were controlled by periodic spraying with approved pesticides. Plots were harvested when the grain had about $20 \%$ moisture and was dried to $12 \%$. 


\section{RESULTS AND DISCUSSION}

Table 1 shows that with broadcast seeding, yields of the Girona variety increased when seeding rates were increased from 70 to $115 \mathrm{~kg} / \mathrm{hg}$, but further increases in seeding rates did not significantly affect yields. Yields of the Bahía variety were not affected by seeding rates ranging from 70 to $155 \mathrm{~kg} / \mathrm{ha}$.

Yields of the Caloro variety were not affected by seeding rates when planted in rows 20 to $30 \mathrm{~cm}$ apart, but yields were higher with the $20-\mathrm{cm}$ spacing. Yields obtained in this experiment were similar to those produced in other experiments in the relatively low yielding August-September plantings.

Table 2 shows that increasing seeding rates from 110 to $450 \mathrm{~kg} / \mathrm{ha}$ did not affect yields of the Brazos variety, but a further increase to $560 \mathrm{~kg}$ of

TABLE 1.-Effect of seeding rates on yields of rough rice produced by three short grain varieties at Gurabo

\begin{tabular}{cllll}
\hline \multirow{2}{*}{ Seeding rate ${ }^{1}$} & \multicolumn{4}{c}{ Yields of rough rice (kg/ha) } \\
\cline { 2 - 5 } & $\begin{array}{c}\text { Girona } \\
\text { broadcast }\end{array}$ & $\begin{array}{c}\text { Bahía } \\
\text { broadcast }\end{array}$ & $\begin{array}{c}\text { Caloro in 20- } \\
\text { cm rows }\end{array}$ & $\begin{array}{c}\text { Caloro in 30- } \\
\text { cm rows }\end{array}$ \\
\hline$k g / h a$ & & & & \\
70 & $4211 \mathrm{~b}^{2}$ & $4547 \mathrm{a}$ & $5096 \mathrm{a}^{* 3}$ & $4278 \mathrm{a}^{* 3}$ \\
90 & $4458 \mathrm{a}, \mathrm{b}$ & $4917 \mathrm{a}$ & $4364 \mathrm{a}$ & $4614 \mathrm{a}$ \\
115 & $4794 \mathrm{a}$ & $4637 \mathrm{a}$ & $5130 \mathrm{a}^{*}$ & $4300 \mathrm{a}^{*}$ \\
135 & $4883 \mathrm{a}$ & $4670 \mathrm{a}$ & $4816 \mathrm{a}^{*}$ & $4278 \mathrm{a}^{*}$ \\
155 & $4704 \mathrm{a}$ & $4950 \mathrm{a}$ & - & - \\
\hline
\end{tabular}

${ }^{1}$ Seed with $90 \%$ germination.

${ }^{2}$ Values in columns with one or more letters in common do not differ statistically (Duncan's multiple range test).

${ }^{3}$ Values in rows show significant differences at the $5 \%$ probability level.

seed/ha reduced yields. Plant height at harvesting decreased with increased seeding rates. At the $560-\mathrm{kg} / \mathrm{h}$ a seeding rate, plants were smaller, had smaller panicles, and tillering was drastically reduced. Average yields were similar to those obtained with this variety in other experiments planted at a similar time (February) by Lozano and Abruña (6).

Table 2 also shows that about 20\% lodging occurred at the 450 - and $560-\mathrm{kg} / \mathrm{ha}$ seeding rates; also that blast (Piricularia oryzae) was kept under control even at the very high seeding rates by spraying. Brazos is susceptible to blast, especially when high nitrogen rates are used (8).

In general, it seems best to plant about $120 \mathrm{~kg}$ of seed (90\% germination) per hectare with all varieties. Although much heavier seeding rates can be tolerated by the Brazos variety, with no effect on yields, lodging is more acute, and there is more damage by blast even with a good spray program. 
Table 3 shows that yields of the very early maturing Girona variety were drastically reduced when the seedlings were transplanted later than 30 days after seeding. Transplanting 20 or 30 days after seeding resulted in similar yields. Transplanting at 40 days resulted in smaller plants than transplanting at an earlier date. On the average, the rice was harvested 90 days after seeding. When the seedlings were transplanted 40 days after seeding, this very early variety, which blooms about 60 days after seeding, had only 20 days to grow in the field and produce a panicle. Sánchez and Larrea (12) have shown that late maturing varieties are less affected by late transplanting.

TABLE 2.-Effect of seeding rate on yields, plant height and infestation with blast on the Brazos variety

\begin{tabular}{ccccc}
\hline Seeding rate $^{1}$ & $\begin{array}{c}\text { Yields of } \\
\text { rough rice }\end{array}$ & $\begin{array}{c}\text { Height of } \\
\text { plant at har- } \\
\text { vesting }\end{array}$ & Lodging & $\begin{array}{c}\text { Infestation } \\
\text { with blast }\end{array}$ \\
\hline $\mathrm{kg} / \mathrm{ha}$ & $\mathrm{kg} / \mathrm{ha}$ & $\mathrm{cm}$ & $\%$ & $\%$ \\
110 & $6864 \mathrm{a}^{2}$ & $68 \mathrm{a}$ & 0 & 0 \\
225 & $7275 \mathrm{a}$ & $65 \mathrm{~b}$ & 3 & 1 \\
336 & $7473 \mathrm{a}$ & $60 \mathrm{c}$ & 0 & 3 \\
450 & $7275 \mathrm{a}$ & $58 \mathrm{c}$ & 20 & 10 \\
560 & $6254 \mathrm{~b}$ & $54 \mathrm{~d}$ & 20 & 15 \\
\hline
\end{tabular}

${ }^{1}$ Seed with $88 \%$ germination.

${ }^{2}$ Values in columns with one or more letters in common do not differ statistically (Duncan's multiple range test).

TABLE 3.-Effect of age of seedling at transplanting on growth habit and yields of the Girona variety

\begin{tabular}{cccc}
\hline $\begin{array}{c}\text { Age at trans- } \\
\text { planting }\end{array}$ & $\begin{array}{c}\text { Yields of } \\
\text { rough rice }\end{array}$ & $\begin{array}{c}\text { Height at } \\
\text { flowering }\end{array}$ & $\begin{array}{c}\text { Days from } \\
\text { seeding to ma- } \\
\text { turity }\end{array}$ \\
\hline Days & $\mathrm{kg} / \mathrm{ha}$ & $\mathrm{cm}$ & \\
20 & $6379 \mathrm{a}^{2}$ & $73 \mathrm{a}$ & $87 \mathrm{a}$ \\
30 & $6626 \mathrm{a}$ & $75 \mathrm{a}$ & $90 \mathrm{a}$ \\
40 & $3739 \mathrm{~b}$ & $62 \mathrm{~b}$ & $92 \mathrm{a}$ \\
\hline
\end{tabular}

${ }^{1}$ At $12 \%$ moisture.

${ }^{2}$ Values in columns with one or more letters in common do not differ statistically (Duncan's multiple range test).

The following tabulation shows that the Girona variety produced similar yields when transplanted 21 days after seeding, as compared to direct seeding:

\section{Planting system \\ Direct seeding \\ Transplanting 5\% L.S.D.}

\section{Yields of rough rice} $(\mathrm{kg} / \mathrm{ha})$ 5403 5728 468 
The transplanted rice produced a crop 60 days after transplanting or 91 after seeding, while the direct-seeded plots produced a crop in 95 days.

If it were possible to plant continuously, theoretically 3.8 crops of Girona could be produced yearly by direct seeding and 5.2 crops by transplanting. Assuming an average yield of $5 \mathrm{t} / \mathrm{ha}$ per crop, a total of 19 tons could be produced per hectare annually with direct seeding, and 26 $\mathrm{t}$ with transplanting.

Although it is not practical to transplant rice in Puerto Rico because of high labor costs, production could be increased in areas of subsistence farming in Central America and the Caribbean by transplanting early varieties and planting continuously where water is abundant. Where rainfall is only seasonally abundant, production could be increased by transplanting two crops during the rainy season.

\section{RESUMEN}

El rendimiento de la variedad Caloro no se afectó al variar la cantidad de semilla de 70 a $135 \mathrm{~kg} /$ ha cuando se sembró en hileras a 20 y $30 \mathrm{~cm}$ de separación, pero su rendimiento fue mayor en las hileras a $20 \mathrm{~cm}$.

El rendimiento de la variedad Girona sembrada a voleo aumentó significativamente cuando la cantidad de semilla se aumentó de 70 a $115 \mathrm{~kg} / \mathrm{ha}$. Aumentos adicionales en la cantidad de semilla no afectaron el rendimiento. El de la variedad Bahía no se alteró al aumentar la cantidad de semilla de 70 a $155 \mathrm{~kg} / \mathrm{ha}$; y el de la variedad Brazos tampoco se afectó cuando la cantidad de semilla se aumentó en incrementos de 110 a $450 \mathrm{~kg} / \mathrm{ha}$, pero disminuyó cuando la cantidad de semilla se aumentó a $560 \mathrm{~kg} / \mathrm{ha}$.

El transplantar las plántulas de la variedad Girona a los 40 días de sembrada causó una reducción en el rendimiento al compararse con el transplante a los 20 ó 30 días. La Girona produjo rendimientos similares cuando se sembró directamente de semilla o se transplantó a los 21 días. Si se hiciesen siembras continuas, transplantando a los 21 días, teóricamente podrían lograrse 5.2 siembras por año con un rendimiento total de $26 \mathrm{Tm} /$ ha; y en siembra directa de semilla, podrian lograrse 3.8 cosechas y 19 toneladas.

\section{LITERATURE CITED}

1. Brown, F. B., 1958. Some effects of seedling age on transplanted rice, Malay Agric. J. 41 (4): 221-65.

2. Cada, E. and Taleon, S., 1963. The effects of age of seedlings at transplanting upon the growth and yield of early, medium and late maturing varieties, Philipp J. Agric. 28 (4): 115-19.

3. Johnston, T. H. and Miller, M. D., 1973. Culture of rice in the United States: Varieties and production, USDA Agric. Handbook No. 289.

4. Jones, J., Dockings, J. O., Walker, R. L., and Davis, W. C., 1952. Rice production in the southern states, USDA Farmer's Bull. 2043. 
5. Leonard, W. H., 1948. Rice as a crop in Japan, J. Am. Soc. Agron, 40:579-602.

6. Lozano, J. M. and Abruña, F., Season of the year on yield of seven medium grain rice varieties, J. Agric. Univ. P.R. 66 (3):188-93.

7. _— and —, 1977. Effect of planting season on yield of eight short-grain varieties of rice under irrigation, J. Agric. Univ. P.R. 61 (1): 6-10.

8. - - and - - Nitrogen rates applied in single and split applications and yields of flooded rice, J. Agric. Univ. P.R. 65 (1): 35-42.

9. Lugo-López, M. A. and Rivera, Luis, H., 1977. Updated taxonomic classification of the soils of Puerto Rico, Univ. P.R. Agric. Exp. Stn. Bull. 258.

10. Nelson, M., 1931. Preliminary report on cultural and fertilizer experiments with rice in Arkansas, Ark. Agric. Exp. Stn. Bull. 264.

11. Reynolds, E. G., 1954. Research on rice production in Texas. Texas Agric. Exp. Stn. Bull. 775 .

12. Sánchez, P. A. and Larrea, N. L., 1972. Influence of seedling age at transplanting on rice performance, Agron. J. 64: 828-33.

13. - - 1976. Soil management in rice cultivation systems. Properties and management of soils in the tropics, John Wiley and Sons.

14. Simmons, C, F., 1940. Rice production and riceland uses in Arkansas, Ark. Agric. Ext. Serv. Cir. 424. 